\title{
ZNACZENIE SEKTORA BANKOWEGO W FINANSOWANIU POLSKIEGO ZADŁUŻENIA PUBLICZNEGO WOBEC ZMIAN NA EUROPEJSKICH RYNKACH FINANSOWYCH
}

\section{Wprowadzenie}

Rynek finansowy pełni służebną rolę wobec gospodarki realnej, ponieważ zapewnia transfer kapitału od podmiotów posiadających nadwyżki do tych, które odczuwają jego niedostatek. Problemem szeroko analizowanym we współczesnej literaturze światowej jest efektywność rynków finansowych w procesie zaopatrywania w kapitał przedsiębiorstw i gospodarstw domowych, nieco rzadziej państwa. Niemniej Skarb Państwa ${ }^{1}$, podobnie jak inne podmioty życia gospodarczego, jest uczestnikiem rynków finansowych, co więcej, adekwatnie do przedsiębiorstw i gospodarstw domowych może potrzebować środków pieniężnych w celu zbilansowania własnego salda z powodu niezsynchronizowania przepływów budżetowych, co wynika z ich strumieniowej natury. Jak pokazały doświadczenia większości państw w czasie ostatniego kryzysu, deficyt finansów publicznych może gwałtownie wzrastać i generować coraz większy dług publiczny nie tylko za sprawą planowanej w ustawie budżetowej nierównowagi wydatkowo-dochodowej, ale także w wyniku innych działań gospodarczych, np. stosowania keynesowskich metod przywracania koniunktury - aktywnej polityki budżetowej. Jej szeroko zakrojone użycie w ostatnich latach było możliwe dzięki pożyczkom zaciąganym na rynkach finansowych w wielkościach wcześniej niezakładanych ${ }^{2}$. Trzeba także pamiętać, że wymierna część tych środków (pożyczkowych) pochodziła właśnie z sektora bankowego, który kreował popyt na emitowane przez Skarb Państwa bony i obligacje skarbowe. Doceniając możliwość akumulacji kapitału tym sposobem, warto jednak zastanowić się nad kwestią finansowania rosnącego zadłużenia publicznego przez banki w warunkach nowej architektury finansowej - tworzonej w odpowiedzi na trwający kryzys. Innymi słowy, jak - w stosunku do

\footnotetext{
1 Skarb Państwa jest jednym z trzech podmiotów sektora budżetowego, które zgłaszają popyt na kredyt bankowy. Raport o sytuacji banków w 2010, UKNF, Warszawa 2011, s. 26.

2 Ponieważ ingerowanie państwa $\mathrm{w}$ gospodarkę nie jest działaniem standardowym, nie posiada jednolitej i sztywnej struktury. W. Wrzosek, Funkcjonowanie rynku, PWE, Warszawa 1997, s. 378.
} 
sytuacji dotychczasowej - może kształtować się popyt ze strony sektora bankowego na skarbowe papiery wartościowe w przyszłości i od czego może być on uzależniony.

\section{Finansowanie zadłużenia publicznego fundamentem funkcjonowania współczesnej gospodarki}

Problemem systemów gospodarczych na całym świecie jest wielkość zadłużenia publicznego, rosnącego niezależnie od fazy cyklu koniunkturalnego. Ostatni kryzys finansowy wcale nie zapoczątkował przyrostu poziomu wierzytelności publicznych w przypadku większości systemów gospodarczych. Zredukował jedynie wzrost gospodarczy, który je skrzętnie kamuflował’. W dodatku od roku 2008 pojawiła się konieczność stymulowania realnych gospodarek narodowych oraz poprawianie płynności rynków finansowych, co zwiększyło zapotrzebowanie państw na kapitał pożyczkowy. Na tym gruncie rozkwitła na nowo aktywna polityka budżetowa (powrót do keynesowskich metod ożywiania koniunktury ${ }^{4}$ ), wykorzystująca paradoks niezbilansowanego budżetu do przejściowego przywracania równowagi gospodarce. Zarówno wspomniany niski (lub ujemny) wzrost PKB, jak i ekspansywna polityka wydatkowa rządów sprawiły, że zadłużenie publiczne zaczęło narastać zarówno w ujęciu wartościowym, jak i relatywnym (względem PKB) w oszałamiającym tempie, nierzadko przekraczając określone ustawami ramy zobowiązań (np. USA - zmiany w ustawie zasadniczej). Wraz z przedłużającym się kryzysem wierzytelności publiczne rosły również jako efekt spadku wiarygodności kredytowej emitentów. To z kolei wymuszało na rządach uwzględnianie coraz wyższych premii za ryzyko w rentowności oferowanych bonów i obligacji skarbowych, niezbędne, aby podaż znalazła swój popyt. W takich warunkach znajdowanie odbiorców chętnych do inwestowania wolnych środków w instrumenty zadłużeniowe państw stanowiło fundament funkcjonowania wielu narodowych systemów gospodarczych, zwłaszcza $\mathrm{z}$ tego powodu, że dotychczasowi inwestorzy bankrutowali, przeżywali kłopoty finansowe lub popadali w coraz większą niechęć do ryzyka, które - wbrew potocznym opiniom - jest wkomponowane także w skarbowe instrumenty dłużne, czego dowodem są obligacje skarbowe Grecji.

${ }^{3}$ G. Waszkiewicz, Zadłużenie publiczne a koniunktura gospodarcza, „Zeszyty Naukowe IEiZ” nr 15, Wydawnictwo Politechniki Koszalińskiej, Koszalin 2011, s. 210-212.

${ }^{4}$ M. Krawczyk, Deficyt budżetu państwa i aktywność gospodarcza, „Ekonomista” nr 5, 2009, s. 561-568. 


\section{Odbiorcy rządowych papierów dłużnych a zalecenia strategii zarządzania długiem sektora finansów publicznych w Polsce}

Zaciąganie pożyczek publicznych ma miejsce na rynkach finansowych, gdzie skarbowe papiery dłużne znajdują swoich nabywców. Zbywanie rynkowych skarbowych papierów wartościowych pozwala Skarbowi Państwa gromadzić brakujący kapitał, jednocześnie powinno służyć kreowaniu optymalnych struktur zadłużeniowych, tzn. portfela zadłużenia odpornego na zaburzenia gospodarcze. Ramy optymalizacji struktur zobowiązań na kolejne trzy lata wytycza Minister Finansów w strategii zarządzania długiem sektora finansów publicznych. Decyzje optymalizacyjne, uwzględniające instytucje bankowe jako grupę inwestorską, odnoszą się do: ograniczania jej udziału wśród odbiorców krajowych skarbowych papierów wartościowych, kontrolowania wielkości zobowiązań zagranicznych z uwagi na zaangażowanie banków zagranicznych oraz wydłużanie horyzontu zapadalności plasowanych instrumentów skarbowych, czemu służą emisje zagraniczne. Analiza wszystkich aspektów kreowania stabilnych struktur zadłużenia, z uwagi na zaangażowanie podmiotów bankowych w tym procesie, prowadzi do dwóch dylematów natury merytorycznej: 1) Proporcja: dług krajowy - dług zagraniczny

Podział całości zadłużenia państwa na te dwie kategorie materializuje się poprzez emisję obligacji w walucie polskiej na rynku krajowym oraz emisję w walucie kraju, w którym owe obligacje będą zbywane - na rynku zagranicznym. Obligacje zagraniczne w zdecydowanej mierze odnoszą się do skarbowych papierów wartosciowych denominowanych w euro i zbywanych na rynkach krajów wspólnego obszaru walutowego ${ }^{5}$. Z punktu widzenia zarządzających długiem publicznym zwiększanie zadłużenia państwa poza granicami kraju pozytywnie wpływa na kreowanie odpornych struktur długu, ale jednocześnie rodzi zagrożenie makroekonomiczne wynikające z uzależnienia się od zagranicy. Jest to szczególnie niebezpieczne ze względu na wahania wartości waluty krajowej, bowiem jej osłabienie sprawia, że wartość długu denominowanego w walutach obcych rośnie i podnosi zagregowaną sumę zobowiązań państwa. Co więcej, jeśli zbyt duża ilość zobowiązań zostanie wyemitowana na rynkach obcych, a sytuacja makroekonomiczna kraju ulegnie pogorszeniu, to nastąpi wyprzedaż tych aktywów przez inwestorów z zewnątrz w terminie ich zapadalności.

5 W strukturze walutowej zadłużenia Skarbu Państwa za 2010 rok niemal 20\% zadłużenia stanowi dług w walucie euro. Strategia zarządzania długiem sektora finansów publicznych w latach 2012-2015, MF, Warszawa 2011, s. 10. 
Wówczas państwo nie będzie mogło rolować długu i obsługiwać całości jego kosztów na rynkach zagranicznych za pomocą skarbowych papierów wartościowych i w efekcie będzie zmuszone do zaciągania kredytów w międzynarodowych instytucjach finansowych ${ }^{6}$. Warto także zauważyć, że masowa ucieczka inwestorów od skarbowych papierów wartościowych danego kraju może powodować tendencje deprecjacyjne waluty lokalnej - wahania kursowe. Ostatecznie nie jest interesem kraju emitenta (np. Polski) nadmierne zadłużanie się na rynkach zagranicznych i dlatego strategia zarządzania długiem przewiduje ten pułap w przedziale $20-30 \%^{7}$, zwiększany bądź zmniejszany w powiązaniu z sytuacją na międzynarodowych rynkach finansowych.

2) Udział sektora bankowego w zadłużeniu wewnętrznym

Istota kolejnego problemu sprowadza się do roli, jaką powinien odgrywać kapitał pochodzenia bankowego w pokrywaniu całości krajowych potrzeb pożyczkowych Skarbu Państwa. Zadłużenie zewnętrzne Skarbu Państwa zmniejsza skalę efektu wypychania $w$ rodzimej gospodarce, gdyż ogranicza przejmowanie przez państwo kapitału z lokalnego rynków finansowego. Jest to jedno z głównych ograniczeń ${ }^{8}$ angażowania sektora bankowego w proces fundowania długu publicznego. Realizowane poprzez zmniejszanie znaczenia banków $\mathrm{w}$ finansowaniu potrzeb państwa, albowiem na instytucjach bankowych spoczywa przede wszystkim odpowiedzialność za kredytowanie sfery realnej, kreującej wzrost gospodarczy. Zatem sednem działań Ministerstwa Finansów w tym zakresie jest optymalizacja struktury pozyskiwanego kapitału pożyczkowego drogą dywersyfikacji grup inwestorskich, najchętniej z sektora niebankowego, tj. z funduszy inwestycyjnych, zakładów ubezpieczeń, od inwestorów indywidualnych i zagranicznych (nierezydentów) (rysunek 1a).

Warto jednak zaznaczyć, że zainteresowanie skarbowymi papierami wartościowymi ze strony banków jest zdecydowanie mniej stabilne aniżeli ze strony instytucji niebankowych ze względu na horyzont inwestycyjny ${ }^{9}$. Banki preferują inwestycje w bony skarbowe, zwłaszcza gdy te oferują dochodowości wyższe niż oprocentowanie kredytów lub operacji otwartego rynku, zatem popyt banków na bony Skarbu Państwa rośnie w sytuacji napięć budżetowych, gdy polityka fiskalna jest niepewna.

6 Dług publiczny - raport roczny 2010, MF, Warszawa 2011, s. 59.

7 Szerzej: Ocena stopnia realizacji strategii w: Strategia zarządzania... (2007-2009, 2008-2010, 2009_ -2011, 2012-2015), op.cit.

8 Poza tym angażowanie banków to zwiększanie ich popytu na instrumenty rynku pieniężnego pogarszanie struktury zapadalności. Zaś z punktu widzenia prowadzenia polityki gospodarczej nadmierne pozyskiwanie bonów skarbowych przez banki utrudnia prowadzenie polityki monetarnej (patrząc szerzej - koordynację policy mix).

9 Strategia zarzadzania... 2012-2015, op.cit., s. 24. 
Rysunek 1. Nabywcy polskich skarbowych instrumentów dłużnych

\begin{tabular}{|l|c|}
\multicolumn{2}{|c|}{$\begin{array}{c}\text { Rynek zbytu } \\
\text { dłużnych papierów skarbowych }\end{array}$} \\
\begin{tabular}{l|l|} 
a) Wewnętrzny rynek finansowy & b) Zewnętrzne rynki finansowe \\
1) banki komercyjne & 1) banki centralne \\
2) fundusze emerytalne & 2) banki komercyjne \\
3) inwestorzy indywidualni & 3) fundusze emerytalne \\
5) inwestorzy zagraniczni (patrz b) & 4) zakłady ubezpieczeń \\
5) inwestorzy indywidualni
\end{tabular} \\
\hline
\end{tabular}

Źródło: Opracowanie własne na podstawie: K. Marchewka-Bartkowiak, Zarzadzanie długiem publicznym. Teoria i praktyka państw Unii Europejskiej, PWN, Warszawa 2008, s. 161-167; K. Jajuga, T. Jajuga, Inwestycje - instrumenty finansowe, aktywa finansowe, ryzyko finansowe, inżynieria finansowa, PWN, Warszawa 2006, s. 69-72.

Wśród inwestorów tworzących popyt na krajowe papiery skarbowe coraz prężniej rozwija się sektor kapitałodawców pochodzenia obcego [banki centralne i komercyjne, fundusze inwestycyjne oraz towarzystwa ubezpieczeniowe (rysunek 1, 1a5)]. Zaangażowanie inwestorów z zewnątrz daje możliwości plasowania instrumentów skarbowych na rynku lokalnym bez obciążania rodzimego systemu finansowego, stąd udział nierezydentów jest pożądany, zwłaszcza gdy dotyczy narzędzi rynku kapitałowego - obligacji o najdłuższym horyzoncie czasowym. Jednakże zgłaszany przez nich popyt trudno uznać za stabilny, gdyż jest uzależniony od sytuacji międzynarodowej (finansowej), w efekcie korekta w dół pozycji nierezdentów na rynku krajowym może powodować niestabilność waluty lokalnej, może również utrudniać zaciąganie długu na rynkach zagranicznych ${ }^{10}$.

Uwzględniając kierunki działań na składnikach polskiego zadłużenia, precyzowane w strategiach Ministerstwa Finansów w kontekście marginalizowania znaczenia krajowego sektora bankowego jako odbiorcy rządowych papierów dłużnych, można stwierdzić, że udział banków krajowych w rynku zadłużeniowym powinien wynikać z konieczności zachowania przez nie podstawowej płynności finansowej (popyt na bony skarbowe ${ }^{11}$ ) oraz chęci podejmowania inwestycji długoterminowych.

10 Ibidem, s. 26.

11 Pod ich zastaw można uzyskać kredyt lombardowy, którego wielkość jest uzależniona od wielkości funduszów banku. Szerzej: I.D. Czechowska, Bony pieniężne i skarbowe - instrumenty komplementarne 


\section{Fundowanie polskiego zadłużenia przez banki a koniunktura gospodarcza (dane z lat 2006-2010)}

Zmiany w popycie na bony i obligacje Skarbu Państwa w latach 2006-2010 prowadzą do kilku istotnych spostrzeżeń. W okresie koniunktury gospodarczej możemy mówić o świadomym i celowym ograniczaniu podaży instrumentów zadłużeniowych, a w ślad za nią popytu na bony skarbowe ze strony banków komercyjnych. Widać to na przykładach z lat 2006 i 2007, kiedy to optymalizowano strukturę zadłużenia, obniżając udział instrumentów rynku pieniężnego (tabela 2), ale również utrzymywano na niskim poziomie udział sektora bankowego w finansowaniu krajowych potrzeb pożyczkowych (23\%) (tabela 1). Co więcej, poziom emisji zagranicznych był zgodny z optymalnym, przyjętym w strategii zarządzania długiem sektora finansów publicznych.

Sytuacja uległa całkowitej zmianie wraz z rozwojem kryzysu finansowego w roku 2008, kiedy problemy banków amerykańskich (Merrill Lynch, AIG, Lehman Brothers), a następnie angielskich (Northern Rock) wywołały niespotykaną awersję do ryzyka. Warto przy tym dodać, że o ile w czasie prosperity banki są skrajnie nieostrożne w ocenie ryzyka kredytowego, o tyle podczas dekoniunktury pojawia się u nich nadmierna niechęć do ryzyka ${ }^{12}$. Wszechobecna niepewność powodowała, że banki na całym świecie stawały się coraz mniej płynne, niechętne do udzielania kredytów, nieufne nawet względem siebie, co groziło spadkiem aktywności gospodarczej. W tym momencie na pierwszy plan wysunęła się aktywna polityka budżetowa (stabilizacyjna). W wielu krajach starano się przywracać przejściowo równowagę i stwarzać warunki do odbicia gospodarczego. Niemniej stosowanie impulsu fiskalnego dla ożywienia gospodarek realnych oraz angażowanie środków budżetowych dla poprawy płynności na rynkach międzybankowych miało jedną wadę - wymagało zaciągania kolejnych zobowiązań przez państwa. Tym sposobem walka z kryzysem finansowym stopniowo pogarszała sytuację krajowych finansów publicznych. Rosło ryzyko kredytowe poszczególnych emitentów skarbowych papierów wartościowych i wzrastały koszty obsługi zadłużenia. Z biegiem czasu okazało się również, że niektóre z państw strefy euro, uznawanej dotąd za najbezpieczniejszą przystań, zatraciły zdolność regulowania swoich zobowiązań (Irlandia, Grecja). Tym samym kryzys finansowy przerodził się w kryzys finansów publicznych.

czy substytuty dla banku komercyjnego, w: Instytucje, instrumenty i strategie finansowe $w$ dobie integracji gospodarczej - bankowość, red. J. Węcławski, Wydawnictwo UMCS, Lublin 2006, s. 293-294.

12 H. Minsky, Stabilizing and unstable economy, McGraw-Hill, International ed. 2008. 
Tabela 1. Zmiany w popycie na polskie skarbowe papiery wartościowe (w mld zł; 2006-2010)

\begin{tabular}{|c|c|c|c|c|c|c|c|}
\hline \multirow{5}{*}{ Rok } & \multicolumn{7}{|c|}{ Dług względem miejsca emisji i sektorów } \\
\hline & $\mathrm{a}$ & a1 & & & a2 & & $\mathrm{b}$ \\
\hline & \multirow{3}{*}{$\begin{array}{c}\text { zadłużenie } \\
\text { Polski } \\
\text { w skarbowych } \\
\text { papierach } \\
\text { wartościowych }\end{array}$} & \multirow{3}{*}{$\begin{array}{c}\text { emisje } \\
\text { zagraniczne } \\
\text { [a1/a] }\end{array}$} & \multicolumn{4}{|c|}{ emisje krajowe } & \multirow{3}{*}{$\begin{array}{c}\text { kapitał obcy } \\
\text { fundujący } \\
\text { potrzeby } \\
\text { pożyczkowe } \\
\text { w kraju } \\
\text { i za granicą } \\
\text { b= a1 + } \\
\text { a2, d [/a] }\end{array}$} \\
\hline & & & \multirow[b]{2}{*}{ a) ogólnie } & \multicolumn{2}{|c|}{ krajowy sektor finansowy } & \multirow[b]{2}{*}{$\begin{array}{l}\text { d) inwestorzy } \\
\text { zagraniczni } \\
{[a 2, d / a 2, a]}\end{array}$} & \\
\hline & & & & $\begin{array}{l}\text { b) bankowy } \\
{[\mathrm{a} 2, \mathrm{~b} / \mathrm{a} 2, \mathrm{a}]}\end{array}$ & $\begin{array}{l}\text { c) pozabankowy } \\
{[\mathrm{a} 2, \mathrm{c} / \mathrm{a} 2, \mathrm{a}]}\end{array}$ & & \\
\hline 2006 & 478,5 & $126,2\left[26,4^{\mathrm{a}}\right]$ & 352,3 & $80,6[23,0]$ & $197,3[56,0]$ & $74,4[21,0]$ & $200,6[42,0]$ \\
\hline 2007 & 501,5 & $121,1[24,1]$ & 380,4 & $87,9[23,1]$ & $218,0[57,0]$ & $74,5[19,6]$ & $195,5[39,0]$ \\
\hline 2008 & 569,9 & $149,7[26,3]$ & 420,2 & $135,6[32,3]$ & $228,6[54,4]$ & $56,0[13,3]$ & $205,7[36,0]$ \\
\hline 2009 & 631,5 & $168,8[26,7]$ & 462,7 & $146,0[31,5]$ & $234,9[50,7]$ & $81,8[17,8]$ & $250,6[40,0]$ \\
\hline 2010 & 701,8 & $194,8[27,8]$ & 507,0 & $130,5[25,7]$ & $248,2[49,0]$ & $128,3[25,3]$ & $323,1[46,0]$ \\
\hline
\end{tabular}

${ }^{\mathrm{a}}$ Dane w \%.

Źródło: Opracowanie własne na podstawie: Dług publiczny - raport roczny, MF, Warszawa 2010.

Rosnące potrzeby pożyczkowe polskiego rządu, które ujawniły się w 2008 roku, były efektem obniżających się wpływów budżetowych przy jednoczesnym rozrastaniu się strony wydatkowej budżetu - działanie automatycznych stabilizatorów koniunktury. W rezultacie państwo musiało zwiększyć planowane dochody do budżetu, aby sfinansować rosnące wydatki. Konieczność doraźnego bilansowania budżetu zmusiła Ministerstwo Finansów do kolejnych emisji skarbowych papierów wartościowych, w głównej mierze instrumentów krótkoterminowych, na co oddziaływały ${ }^{13}$ : ucieczka inwestorów zagranicznych z polskiego rynku finansowego, w tym zadłużeniowego (tabela 1, a2d), pogarszająca się sytuacja finansowa polskiego sektora niebankowego ( $\mathrm{tj}$. fundusze inwestycyjne), rosnąca presja inflacyjna oraz wyższe zainteresowanie bonami skarbowymi. W rezultacie pomiędzy rokiem 2007 a 2008 drastycznie wzrosła wartość długu publicznego wyemitowanego na rynku pieniężnym (+27,8 mld zł - tabela 2), która w warunkach ograniczonego popytu na instrumenty kapitałowe znalazła swoich odbiorców w sektorze bankowym. Między II kwartałem 2008 roku a I kwartałem 2009 roku udział bonów i obligacji Skarbu Państwa w portfelu banków krajowych wzrósł o ponad 50 mld zł (rysunek 2). Uciekający kapitał obcy spowodował, po pierwsze, spadek aktywów instytucji niebankowych, a za tym podążał limitowany

13 Szerzej: G. Waszkiewicz, Równoważenie budżetu i podnoszenie sprawności rynku obsługi długu publicznego na przykładzie Polski w latach 2007/2008, „Zeszyty Naukowe IEiZ” nr 14, Wydawnictwo Politechniki Koszalińskiej, Koszalin 2010, s. 252-253. 
popyt tych instytucji na instrumenty skarbowe ${ }^{14}$, po drugie, odwrót nierezydentów od krajowego rynku polskich papierów skarbowych, gdzie zagraniczny sektor niebankowy stanowi $70 \%$, a bankowy $20 \%$ całości inwestycji ${ }^{15}$. Ostatecznie w pierwszej fazie kryzysu nastąpił wyraźny odpływ inwestorów zewnętrznych (spadek o 18,5 mld zł) powodowany niepewnymi prognozami co do rynków regionu Europy Środkowowschodniej, jednakże począwszy od 2009 roku kapitał zewnętrzny powoli powracał na polski rynek długu, co potwierdzają dane zawarte w tabeli 1. Wobec powyższego w latach 2008-2009 ciężar szerszego kredytowania rządu przejęły banki komercyjne, a ich udział w fundowaniu ogółu długu krajowego przekroczył 32\%.

Tabela 2. Zmiana zadłużenia Skarbu Państwa w wybranych instrumentach w stosunku do roku poprzedniego ( $w$ mld $\mathrm{zl}$ )

\begin{tabular}{|c|c|c|c|}
\hline \multirow{2}{*}{ Rok } & \multicolumn{3}{|c|}{ Rynek skarbowych papierów wartościowych } \\
\cline { 2 - 4 } & krajowy & zagraniczny \\
\cline { 2 - 4 } & $+1,4$ & obligacje & obligacje \\
\hline 2006 & $-3,2$ & $+35,9$ & $+9,8$ \\
\hline 2007 & $+\mathbf{2 7 , 8}$ & $+31,2$ & $+10,2$ \\
\hline 2008 & $-2,9$ & $+10,0$ & $+7,8$ \\
\hline 2009 & $-19,6$ & $+45,6$ & $+16,4$ \\
\hline 2010 & & $+63,5$ & $+19,9$ \\
\hline
\end{tabular}

Źródło: Opracowanie własne na podstawie: Dług publiczny - raport roczny, MF, Warszawa 2010.

Można zatem stanowczo stwierdzić, że inwestorem finansującym potrzeby pożyczkowe w niepewnych warunkach makrootoczenia stał się sektor bankowy. Wspomogły taki obrót zdarzeń działania władz monetarnych, ponieważ Narodowy Bank Polski zabezpieczając banki w płynność - gdy te niechętnie kreowały akcję kredytową - spowodował ich nadpłynność. W rezultacie banki kumulowały krótki pieniądz i stopniowo zamieniały go na krótkoterminowe skarbowe papiery wartościowe $^{16}$. Jednakże ze wzrostem popytu bankowego rósł udział instrumentów krótkoterminowych, co dokumentują dane $\mathrm{z}$ lat 2007-2010 zawarte w tabeli 2, a tą drogą pogarszała się stabilność i przewidywalność obsługi emitowanego zadłużenia. $Z$ tego powodu można by domniemywać, że skarbowe papiery wartościowe są dla banków komercyjnych narzędziem, które pozwala im zagospodarować bieżącą nadpłynność. Jednakże dane zamieszczone na rysunku 2 pozwalają wnioskować, że skarbowe papiery wartościowe mogą być również alternatywą inwestycyjną. Oka-

\footnotetext{
14 Ibidem, s. 253-254.

15 Dane za: Strategia zarzadzania... 2012-2015, op.cit., s. 25.

16 M. Pronobis, Reakcja Narodowego Banku Polskiego na kryzys w polskim systemie bankowym, w: Gospodarka w warunkach kryzysu, red. S. Antkiewicz, M. Pronobis, CeDeWu, Warszawa 2009, s. 113-114.
} 
zuje się, że niemal 100\% papierów wartościowych będących w posiadaniu banków krajowych w Polsce stanowią instrumenty dłużne. Co więcej, w latach 2006-2010 w portfelu papierów wartościowych instytucji bankowych kluczową rolę odgrywały bony i obligacje skarbowe, których średnia wartość kształtowała się na poziomie $74,7 \%{ }^{17}$. Wobec tego zaangażowanie banków w długoterminowe skarbowe papiery wartościowe można rozpatrywać jako dochodową inwestycję (jak sugeruje M. Zaleska ${ }^{18}$ ), a nie tylko instrument do walki z nadpłynnością, o ile rentowność papierów dłużnych kształtuje się powyżej średniego oprocentowania kredytu dla przedsiębiorstw, a to miało miejsce w 2010 roku. Zauważalny wzrost zainteresowania banków operacjami otwartego rynku (bony pieniężne NBP - rysunek 2) od II kwartału 2009 roku charakteryzuje splot niekorzystnych zdarzeń dla gospodarki, na który złożyło się: ograniczanie akcji kredytowej zarówno dla sfery realnej, jak i budżetowej oraz wzrost kosztów prowadzenia operacji otwartego rynku ${ }^{19}$. Takie działanie instytucji bankowych mogło wynikać z filozofii właścicieli, którzy kształtują politykę inwestycyjną w odniesieniu do sytuacji na międzynarodowych rynkach finansowym oraz we własnym $\mathrm{kraju}^{20}$ i dlatego preferują krótki termin zapadalności w niestabilnych warunkach gospodarczych. Dodatkowo od 2009 roku Ministerstwo Finansów, stosując się do własnych wytycznych w zarządzaniu długiem sektora finansów publicznych, ograniczało emisję instrumentów rynku pieniężnego - $\mathrm{w}$ rezultacie banki rezygnowały $\mathrm{z}$ nich i zwiększały portfel bonów pieniężnych $\mathrm{NBP}^{21}$ (m.in. 7-dniowych, stanowiących narzędzie sterylizacji nadpłynności ${ }^{22}$ ), obligacji Skarbu Państwa (tabela 2).

\footnotetext{
17 Polski rynek finansowy w obliczu kryzysu finansowego w latach 2008- 2009, KNF, Warszawa 2010, s. 58.

18 M. Zaleska, Wyzwania przed bankami, „Gazeta Bankowa” nr 7-8, 2011, s. 40.

19 Ibidem, s. 39-40.

20 Ibidem, s. 40.

${ }^{21}$ Raport o sytuacji..., op.cit., s. 26-27.

22 I.D. Czechowska, Bank Centralny wobec stabilności finansowej, w: W poszukiwaniu efektywności finansów publicznych, red. S. Wieteska, M. Wypych, Wydawnictwo UŁ, Łódź 2009, s. 59.
} 
Rysunek 2. Papiery wartościowe w portfelach banków krajowych; Polska 2006-2009 ( w mld zl)

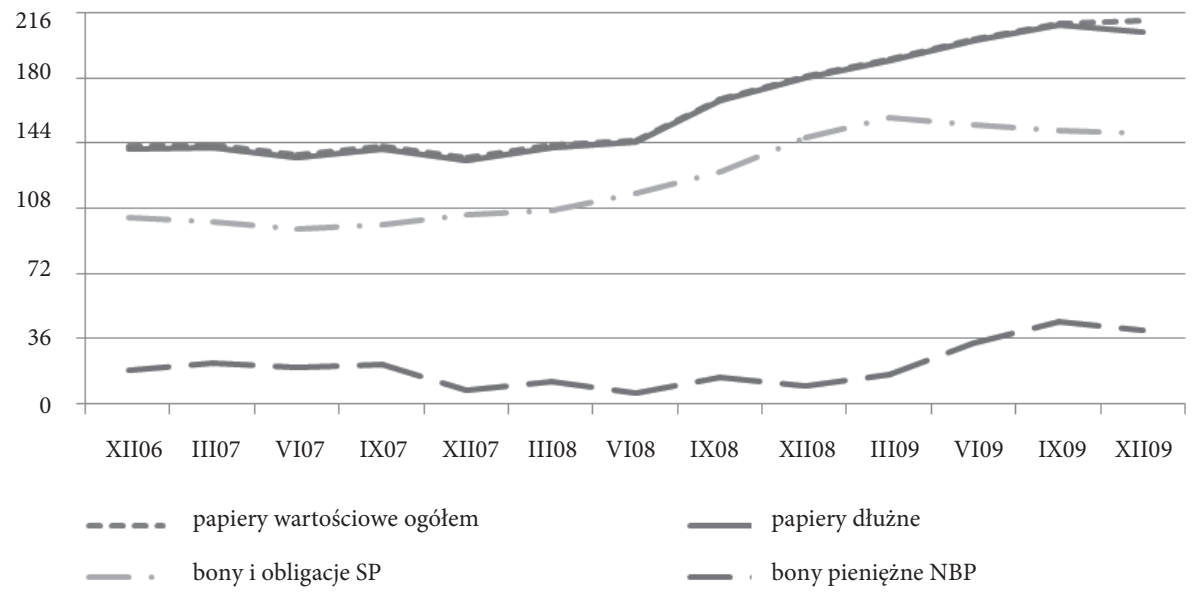

Uwaga: Pominięto obligacje NBP i pozostałe papiery dłużne. Stąd różnica rzędu 20 mld zł pomiędzy wartością papierów wartościowych ogółem a sumą zaprezentowanych (wybranych) składników.

Źródło: Polski rynek finansowy w obliczu kryzysu finansowego w latach 2008-2009, KNF, Warszawa 2010, s. 58.

Podsumowując doświadczenia Polski z lat 2006-2010 w aspekcie fundowania zobowiązań publicznych, można zauważyć, że okres prosperity ułatwia gromadzenie funduszy pożyczkowych w tym sensie, że nie zmusza Skarbu Państwa do nieoczekiwanej aktywności na rynkach zadłużeniowych, bo niedobory budżetu państwa są z góry ustalone. $Z$ tego właśnie powodu ogranicza się rolę banków w finansowaniu państwa, aby te mogły koncentrować się na finansowaniu przedsiębiorstw i gospodarstw domowych. Sytuacja zmienia się jednak radykalnie w czasie recesji bądź kryzysu, kiedy to odpływ inwestorów obcych zmniejsza popyt na rodzime skarbowe papiery wartościowe na rynkach zagranicznych, a przede wszystkim na krajowym rynku zadłużenia, bowiem „odwrót” funduszy zagranicznych osłabia krajowy rynek wierzytelności publicznych dwutorowo: bezpośrednio - poprzez ucieczkę funduszy nierezydentów oraz pośrednio - za sprawą odpływu kapitału z głównych instytucji niebankowych lokalnego systemu finansowego. Taki układ zdarzeń w połączeniu z rosnącym zapotrzebowaniem państwa na kredyt sprawia, że sektorem zdolnym do zabezpieczenia niedoboru środków finansowych w budżecie Skarbu Państwa pozostaje krajowy sektor bankowy, którego udział w finansowaniu zadłużenia publicznego wzrasta tym sposobem. 


\section{Przeobrażenia na europejskich rynkach finansowych a skłonność banków do nabywania skarbowych papierów wartościowych}

Charakteryzując przeobrażenia zachodzące na europejskich rynkach finansowych, warto zwrócić uwagę na ich przesłanki. Zaliczono do nich, po pierwsze, konieczność zmian regulacyjnych w sferze nadzorczej europejskiego systemu finansowego (efekt kryzysu finansowego), po wtóre, sytuację sektora bankowego Unii Europejskiej wobec niezdolności do obsługi własnego zadłużenia przez wybrane kraje emitujące instrumenty skarbowe na międzynarodowych rynkach finansowych (efekt kryzysu zadłużeniowego).

Niepodważalny jest fakt, że rynki finansowe w dobie globalizacji przeżywały swój rozkwit, umożliwiając zarówno akcjonariuszom, jak i zarządzającym realizację olbrzymich zysków. Postępująca finansyzacja ${ }^{23}$ wywołała kryzys finansowy jako efekt nadmiernego zadłużania się obywateli w bankach, które z kolei, niesione chęcią zysku i wiarą w dobrą koniunkturę gospodarczą, odchodziły od filozofii orginate and hold (koncentrującej się na badaniu zdolności kredytowej i monitorowaniu sytuacji kredytobiorcy) i stosowały strategie orginate and distribute - udziel finansowania, podziel i sprzedaj ${ }^{24}$. Było to możliwe jedynie w warunkach postępującej deregulacji rynków finansowych, która stworzyła wiele nowych instrumentów finansowych, np. assets backed securities (ABS), czyli papierów wartościowych zabezpieczonych aktywami banków w postaci udzielonych kredytów, ale również mortgage-backed securities (MBS) - instrumentów zabezpieczonych kredytami hipotecznymi ${ }^{25}$. Wykorzystanie sekurytyzacji pozwalało w pewien sposób omijać wymogi kapitałowe i przepisy nadzorcze ${ }^{26} \mathrm{i}$ transferować ryzyko na inne podmioty rynkowe, które nie były w stanie tego ryzyka ocenić (ułomność agencji ratingowych, asymetria informacji). Z punktu widzenia banków wykorzystanie ABS i MBS umożliwiało utrzymywanie akcji kredytowej bez odniesienia do wartości posiadanych środków własnych.

${ }^{23}$ Przerost sfery finansowej w gospodarce. T. Gruszecki, Przerośnięta sfera, „Gazeta Bankowa” nr 2, 2010, s. 68-69.

24 A. Podurgiel, E. Gastomski, Handel ryzykiem, „Gazeta Bankowa” nr 2, 2010, s. 83.

25 Warto dodać, że na rynki papierów wartościowych trafiały instrumenty sekurytyzowane, które pozwalały bankom transferować ryzyko nie tylko kredytów konsumenckich i inwestycyjnych, ale również hipotecznych. Rozwijający się rynek nieruchomości napędzał rynek kredytów hipotecznych i zmuszał banki do poszukiwania innowacyjnych rozwiązań gwarantujących dopływ kapitału. Szerzej: W. Nawrot, Załamanie rynków papierów wartościowych na tle globalnego kryzysu finansowego, „Finansowy Kwartalnik Internetowy" nr 3, 2009.

26 A. Podurgiel, E. Gastomski, op.cit., s. 84-85. 
Władze europejskie, przeciwdziałając skłonnościom sfery finansowej do odrywania się od gospodarki realnej i nadmiernego rozrostu w przyszłości, podjęły kroki wzmacniające proces kontroli ryzyka banków poprzez nakładanie ograniczeń - regulacji odgórnych, które będą kształtować europejską rzeczywistość finansową za kilka lat. Nowe regulacje będą zapełniały niezagospodarowane obszary lub redefiniowały normy, które ujawniły swoją słabość i okazały się nieskuteczne w czasie kryzysu ${ }^{27}$ - nowa umowa kapitałowa (Basel III), dyrektywa Solvency II $^{28}$. W drodze zmian ukształtowano także zewnętrzny mechanizm ścisłego nadzoru nad przestrzeganiem owych regulacji - Europejska Rada ds. Ryzyka Systemowego oraz Europejski System Organów Nadzoru Finansowego.

Umowa kapitałowa (NUK - Basel III) składa się z trzech wzajemnie powiązanych ze sobą filarów, do których zalicza się: minimalne wymagania kapitałowe, proces nadzorowania i kontroli, a także dyscyplinę działań rynkowych. Można nawet pokusić się o stwierdzenie, że zindywidualizowane podejście do pomiaru ryzyka i stosowanie narzędzi dyscypliny rynkowej przez instytucje bankowe będzie umacniać nadzór nad działalnością bankową ${ }^{29}$. Nie wchodząc w kompleksową analizę proponowanych usprawnień, zawansowane metody zarządzania ryzykiem (zawarte w NUK) mogą wpływać na popyt zgłaszany przez banki na instrumenty zadłużeniowe $\mathrm{z}$ uwagi na ${ }^{30}$ : 1) Nadzór makro- i mikroostrożnościowy

Nadzór makroostrożnościowy (macroprudential), polegający na identyfikacji i analizie ryzyka systemowego oraz przeciwdziałaniu destabilizacji rynków finansowych i gospodarki ${ }^{31}$, będzie realizowany przez Europejską Radę ds. Ryzyka Systemowego (European Systemic Risk Board - ESRB). Jej główne zadanie to ocena stabilności systemu finansowego UE w odniesieniu do rozwoju sytuacji makroekonomicznej oraz ogólnych tendencji na rynkach finansowych ${ }^{32}$. Nadzór mikroostrożnościowy, czyli ocena pojedynczych instytucji rynku finansowego oraz zapewnienie bezpieczeństwa dla nich oraz ich klientów ${ }^{33}$, stanie się domeną Europejskiego Systemu Organów Nadzoru Finansowego (European System of FinancialSupervisors -

${ }_{27}$ M.in. nadmierne zaufanie w stosunku do agencji ratingowych, procykliczność regulacji, możliwość obejścia współczynnika wypłacalności, stosowanie ogromniej dźwigni finansowej, ułomność mechanizmów eksportu ryzyka. Szerzej: P. Bednarski, Bazylea III i jej wyzwania, „Gazeta Bankowa” nr 10, 2010, s. 68.

${ }^{28}$ Solvency II and Basel III. Reciprocal effect should not be ignored, Deutsche Bank Research, www. dbresearch.com (11.12.2011).

${ }^{29}$ J. Krasodomska, Zarządzanie ryzykiem operacyjnym w bankach, PWE, Warszawa 2008, s. 59.

30 P. Bednarski, op.cit., s. 69-70

31 M. Zaleska, Wyzwania przed bankami, op.cit., s. 40.

32 A. Jurkowska-Zeidler, Europejski nadzór finansowy. Nowa architektura, w: Gospodarka - nowe perspektywy po kryzysie, red. M. Kalinowski, M. Pronobis, CeDeWu, Warszawa 2009, s. 34-35.

${ }^{33}$ M. Zaleska, Wyzwania przed bankami, op.cit., s. 40. 
ESFS $^{34}$ ). ESFS będzie czuwał, czy rozporządzenia UE są wprowadzane przez nadzór lokalny - Komisję Nadzoru Finansowego (KNF) w Polsce.

2) Nowe ilościowe normy płynności (wskaźnik pokrycia płynnością oraz wymóg stabilnego finansowania netto)

Wskaźnik pokrycia płynnością (liquidity convergence ratio - LCR) to nominalna i ciągle obowiązująca norma płynności do $30 \mathrm{dni}$, pokazująca, w jakim stopniu bardzo bezpieczne i płynne aktywa pokrywają lukę płynności netto (wpływy - wypływy) w horyzoncie 30-dniowym ${ }^{35}$. Wskaźnik zacznie obowiązywać od 2015 roku. Drugi rozważany wskaźnik to wymóg stabilnego finansowania netto (net stable founding requirements - NSFR). Jest to wskaźnik płynności długoterminowej (dla instrumentów o zapadalności dłuższej niż rok), którego sednem jest zapewnienie wzrostu aktywów długoterminowych i bezpiecznych kosztem instrumentów krótkoterminowych, powiązanych z finansowaniem na rynkach pieniężnych i międzybankowych. Planowane jest wprowadzenie tej normy w roku $2018^{36}$.

3) Bufor ochrony kapitału i antycykliczny mechanizm wzmacniania funduszy własnych

Bufor ochrony kapitału (capital conservation buffer), którego istnienie gwarantuje mandat do narzucenia bankom na zasadach indywidualnych dodatkowego wymogu kapitałowego lub zatrzymania wypłat dywidendy w sytuacji, gdy istniejąca baza kapitałowa jest niewystarczająca w warunkach rosnącego ryzyka banku. Bufor ten jest dodatkowym wymogiem w zakresie kapitałów własnych (dotyczy akcji zwykłych i zysków zatrzymanych), stworzonym z myślą o absorpcji strat w razie kolejnego kryzysu. Bufor ochrony kapitału zostanie wzmocniony buforem antycyklicznym (cuntercyclical buffer), o wprowadzeniu którego będzie decydować KNF, przewidując skutki nadmiernej podaży kredytu. Będzie to norma dla wszystkich banków lokalnych, podnosząca dodatkowo poziom ich wyposażenia w kapitał własny maksymalnie o kolejne $2,5 \%{ }^{37}$.

4) Zmiany dyrektywy UE Solvency II

Zmiany dotyczą wymagań kapitałowych stawianych instytucjom ubezpieczeniowym, w kontekście możliwości lokowania środków własnych w obligacje niezabezpieczone, m.in. banków.

Powyższe przeobrażenia w architekturze finansowej mogą zmuszać banki do modyfikacji własnych strategii inwestycyjnych, co prawdopodobnie będzie powodować zmiany w popycie zgłaszanym przez sektor bankowy, zarówno krajowy, jak

\footnotetext{
34 A. Jurkowska-Zeidler, op.cit., s. 34-35.

35 P. Bednarski, op.cit., s. 69-70.

36 Ibidem, s. 70.

37 Ibidem, s. 71.
} 
i zagraniczny, na polskie papiery skarbowe. LCR, zapewniając wypłacalność i stabilność banków w perspektywie 30-dniowej, spowoduje, że będą one mniej skłonne do nabywania instrumentów krótkoterminowych, zwłaszcza gdy dochodowości nie będą zawyżone. NFTS, dostosowując horyzont zapadalności aktywów i pasywów, sprawi, że instrumenty krótkoterminowe regulujące dotychczas układ aktywa - pasywa nie będą przedmiotem zainteresowania na taką skalę jak przed i w czasie kryzysu, tzn. jeśli bank przyjmie lokatę, będzie zmuszony dostosować do jej zapadalności własną inwestycję. Nie będzie mógł celowo utrzymywać nadpłynności i inwestować w krótkoterminowe papiery skarbowe. Spowoduje to wzrost znaczenia obligacji długoterminowych. Wprowadzane reguły (Basel III, Solvency II) mogą, po pierwsze, faworyzować długoterminowe obligacje zabezpieczone ${ }^{38}$, co zmusi banki do emisji tych instrumentów, a to z kolei spowoduje zamrożenie dodatkowego kapitału - zabezpieczającego ich emisję; po drugie, ograniczać wykorzystanie instrumentów hybrydowych, tworzonych na bazie papierów dłużnych ${ }^{39}$; po trzecie wreszcie, skłaniać instytucje bankowe i niebankowe z UE do inwestycji w skarbowe papiery wartościowe państw, które będzie wyróżniał m.in. niski poziom zadłużenia publicznego ${ }^{40}$. Natomiast kraje z wysokim zadłużeniem będą zmuszone szukać odbiorców za cenę wyższych dochodowości. Poza tym należy pamiętać, że w Polsce zdecydowana większość sektora bankowego podlega ustaleniom w centralach europejskich ${ }^{41}$, gdzie podejmowane będą decyzje co do ekspozycji banków na ryzyko papierów dłużnych danego emitenta. Co więcej, polityka inwestycyjna banków (nierezydentów) może również niekorzystnie wpływać na popyt na polski dług krajowy, gdyż będzie nimi kierować kryterium zadłużenia państw.

Oprócz sfery regulacyjnej pewne zmiany dla rynków zadłużeniowych poszczególnych państw niesie fakt redukcji zadłużenia greckiego o 50\%, tzn. zredukowanie za zgodą banków europejskich (69\% tego zadłużenia znajduje się w posiadaniu banków niemieckich i francuskich ${ }^{42}$ ) zadłużenia greckiego z poziomu 360 mld euro, w tym 200 mld w posiadaniu banków, do 260 mld euro $^{43}$. W efekcie banki europejskie nie odzyskają zainwestowanych pieniędzy w obligacje Grecji. To z kolei może powodować niedostatek kapitału w centralach. Polski sektor bankowy nie jest zaangażowany w obligacje „niepewnych” państw, ale jest zdominowany przez banki

\footnotetext{
38 Solvency II..., op.cit., s. 14.

39 Są to instrumenty finansowe, łączące standardowe instrumenty pochodne (kontrakty futures, opcje i swapy) $\mathrm{z}$ innymi instrumentami finansowymi, zwykle dłużnymi, np. obligacjami.

40 Ibidem, s. 16.

41 W 2010 roku inwestorzy zagraniczni zarządzali 66,2\% aktywów sektora bankowego w Polsce. Raport o sytuacji..., op.cit., s. 13.

${ }_{42}$ M. Zaleska, Bańka w bańkę, „Gazeta Bankowa” nr 12, 2011, s. 74.

43 K. Bojko et al., Europa walczy o zaufanie rynków, „Kwartalnik Finansowy” nr 10-11, 2011, s. 22.
} 
pochodzenia zagranicznego ${ }^{44}$, może zatem rodzić się pokusa dokapitalizowania central przez spółki córki. Taki układ zdarzeń mógłby doprowadzić do zmniejszenia podaży kapitału na polskim rynku finansowym ze strony banków pochodzenia zewnętrznego. Jednakże realnej groźby urzeczywistnienia się tego scenariusza można spodziewać się, gdyby koniecznym okazało się powtórzenie tej samej procedury (redukcja długu) w stosunku do innych zagrożonych państw: Portugalii, Hiszpanii i Włoch.

Wniosek: Ograniczenie zaangażowania banków w finansowanie państwa może wynikać jedynie z niskiej oceny kredytowej i systemowej emitenta.

Podsumowując prezentowany wywód, można uznać, że w dotychczasowych strategiach Ministerstwo Finansów postulowało zawężanie roli banków jako instytucji kreujących popyt na papiery skarbowe, co udawało się realizować jedynie w okresach prosperity. W czasie recesji gospodarczej (co udowodnił ostatni kryzys) inwestorzy, a zwłaszcza inwestorzy zagraniczni odwracają się od niepewnych rynków zadłużeniowych. To miejsce zajmuje krajowy sektor bankowy, tworząc popyt na krótkoterminowe instrumenty dłużne (bony skarbowe), czym pozwala państwu obsługiwać własne zobowiązania, ale także stabilizować chwiejący się wzrost gospodarczy.

Biorąc pod uwagę cele Ministerstwa Finansów (optymalizacja struktur zobowiązań publicznych) oraz banków komercyjnych (spełnienie nowych wymogów kontroli ryzyka), nie podejrzewa się, aby zaangażowanie banków w finansowanie państwa spadło nawet w czasie prosperity. Może natomiast dojść do zmian w zakresie nabywanych przez instytucje bankowe instrumentów, tzn. zwiększania ich popytu na instrumenty długoterminowe wobec stopniowego „odchodzenia” od instrumentów krótkoterminowych - efekt dopasowywania struktury aktywów i pasywów (NFTS). Użycie bonów skarbowych, które stanowią zabezpieczenie kredytów w NBP, może obniżyć się również dlatego, że stosowanie LCR poprawi bieżącą płynność instytucji bankowych, co wraz z zagospodarowaniem ich nadpłynności poprzez dopasowanie aktywów i pasywów banków pozytywnie wpłynie na strukturę zobowiązań Skarbu Państwa - wydłużanie terminu zapadalności. Niemniej z punktu widzenia zarządzających długiem sektora finansów publicznych zaangażowanie banków w proces finansowania wierzytelności publicznych jest szczególnie ważne w czasie dekoniunktury gospodarczej, bądź przedłużającego się kryzysu gospodarczego, bo wówczas niebezpiecznie wzrasta. Jednakże nowe regulacje mogą również implikować pozytywne zmiany w tym względzie - za sprawą wyższego niż dotychczas popytu na obligacje długoterminowe pojmowane jako inwestycja, a także z uwagi na konieczność wypełniania

${ }^{44}$ W 2010 roku dominującą rolę w aktywach polskiego sektora bankowego odgrywał kapitał pochodzący z: Włoch (12,4\%), Niemiec (10,4\%), Holandii (8,6\%), USA (6,9\%) oraz Francji (5,8\%). Raport o sytuacji..., op.cit., s. 13. 
wskaźników płynności ${ }^{45}$. Pozytywnym sygnałem dla rynków zadłużeniowych może być również fakt, że rekapitalizacja banków w związku z redukcją zobowiązań greckich (około 106 mld euro) nie powinna dotknąć polskiego sektora bankowego, bowiem owe środki będą pochodzić przede wszystkim ze wsparcia rządów UE, a w ostateczności z Europejskiego Funduszu Stabilizacji Finansowej (EFSF) ${ }^{46}$.

Konkludując, największe zagrożenie dla stabilności popytu na polskie skarbowe papiery wartościowe ze strony lokalnych instytucji bankowych na rynku wewnętrznym, jak i banków zagranicznych, kreujących zapotrzebowanie na rynkach zagranicznych oraz na rynku krajowym (nierezydenci), może wynikać z surowej oceny ryzyka kredytowego i systemowego emitenta oraz płynności ${ }^{47}$ jego rynku. Zwłaszcza analiza ryzyka systemowego może deklasować polskie zadłużenie w ocenie międzynarodowych rynków finansowych, ponieważ nikt tego wcześniej w Polsce nie realizował ${ }^{48}$.

Inwestorzy bankowi zostaną zmuszeni do wnikliwiej analizy wymienionych grup ryzyka, ponieważ, po pierwsze, zdają sobie doskonale sprawę z faktu, że nawet obligacje skarbowe krajów wspólnego obszaru walutowego nie mogą być klasyfikowane jako w pełni bezpieczne, po drugie, ich polityka inwestycyjna znajdzie się pod stałym nadzorem (microprudential).

Nowe miary oceny i kontroli ryzyka przełożą się natomiast na wzrost znaczenia inwestycji długoterminowych, a zatem aspektem kluczowym co do ewentualnych zmian w popycie na obligacje Skarbu Państwa ze strony banków będzie prowadzona przez państwo polityka gospodarcza, a niskie zadłużenie publiczne stanie się podstawowym kryterium jej oceny.

\section{Significance of banking sector in financing Polish public debt and changes on European financial markets}

The aim of this article is to present the problem of rising amount of public debt, which forces general governments to issue treasury bills and bonds on debt market in order to cover huge expenditures. This process enables balancing budget, however, it requires a wide base of investors (banks, non- banking institution and

45 Basel III and monetary policy, http://www.ecb.int/press/key/date/2010/html/sp100929.en.html (18.12.2011).

$46 \mathrm{http}: / / w w w . f o r b e s . p l / a r t y k u l y /$ sekcje/wydarzenia/europejskie-banki-potrzebuja-106-mld-euro, 21038,1 (20.12.2011).

${ }^{47}$ Nowe standardy płynności będą generować podział papierów skarbowych państw ze względu na płynność ich rynków. Basel III..., op.cit.

48 M. Zaleska, Wyzwania przed bankami, op.cit., s. 41. 
individuals) willing to create demand for public papers. Actions of debt investors are correlated with business cycle what was clearly shown by the last crisis. For this reason, it seems vital to determine present (2006-2010) and future volume of banks' demand, especially in the aftermath of implementing new regulations (Basel III).

First part of this work described correlation between economic cycle and investors' interest in debt service market in the context of Ministry of Finance recommendations. Second part presents mechanisms used to estimate and control risks on European financial markets. What is additionally interesting and complicated is the fact that some of new regulations can have effect on behavior of banks on debt market and their interest in public papers.

\section{L'importance du secteur bancaire dans le financement de la dette publique polonaise face à l'évolution des marchés financiers européens}

Les systèmes économiques contemporains se caractérisent par une nette tendance à s'endetter sur les marchés financiers, ce qui rend nécessaire démettre des bons et des obligations du Trésor. Ce processus permet d’alimenter le budget de l'État, mais il exige également une large base d’acheteurs de titres du trésor (banques, institutions non bancaires, investisseurs individuels). La contribution des groupes d'investisseurs dans la création de la demande pour les valeurs du trésor dépend des conditions économiques, comme l’a démontré la crise actuelle. En se référant à l'expérience des dernières années (2006-2010), on peut indiquer que le secteur bancaire est un acheteur fiable de titres publiques. Cependant, la demande des banques pour les bons du trésor peut changer en raison des nouvelles régulations concernant lévaluation des risques et leur contrôle sur les marchés financiers européens (Bâle III). Il est donc important d'examiner le problème de lengagement des banques commerciales dans les financement de la dette polonaise dans l'avenir, à la fois en raison de l'intérêt de ces institutions et de l'État. 